\title{
A simplified approach to design for assembly
}

\author{
Moultrie, James; Maier, Anja
}

Published in:

Journal of Engineering Design

Link to article, DOI:

10.1080/09544828.2014.887059

Publication date:

2014

Document Version

Peer reviewed version

Link back to DTU Orbit

Citation (APA):

Moultrie, J., \& Maier, A. (2014). A simplified approach to design for assembly. Journal of Engineering Design, 25(1-3), 44-63. https://doi.org/10.1080/09544828.2014.887059

\section{General rights}

Copyright and moral rights for the publications made accessible in the public portal are retained by the authors and/or other copyright owners and it is a condition of accessing publications that users recognise and abide by the legal requirements associated with these rights.

- Users may download and print one copy of any publication from the public portal for the purpose of private study or research.

- You may not further distribute the material or use it for any profit-making activity or commercial gain

- You may freely distribute the URL identifying the publication in the public portal

If you believe that this document breaches copyright please contact us providing details, and we will remove access to the work immediately and investigate your claim 


\title{
A simplified approach to design for assembly
}

\author{
Dr J Moultrie ${ }^{1}$, A M Maier ${ }^{2}$
}

1: Dr James Moultrie, Senior Lecturer in Design, Institute for Manufacturing, Department of Engineering, University of Cambridge, 17 Charles Babbage Road, Cambridge, CB3 0FS, Tel 01223 764830, email jm329@eng.cam.ac.uk (corresponding author)

2: Dr Anja M Maier, Professor, Department of Management Engineering, Building 424, Technical University of Denmark, Tel +45 452560 45, email amai@dtu.dk

\section{Abstract}

The basic principles of Design for Assembly (DfA) are well established. This paper presents a short review of the development of design for assembly approaches before presenting a new tool in which these principles are packaged for use in teams, both in an industrial and an educational context. The fundamental consideration in the design of this tool is to encourage wide team participation from across an organisation and is thus physical rather than software based. This tool builds on the process developed by [Name removed for review] whilst at the [Location removed for review]. In addition to the traditional analysis of component fitting, feeding and fixing, this process also encourages the team to explore how this relates to the overall assembly flow and specifically the achievement of throughput targets. The novel approach is an improvement to established methods and encompasses an original assessment tool and its delivery process that includes custom designed post-it notes and simple check lists for scoring. The process is demonstrated in a single case study in an Indian firm.

\section{Keywords}

Design for Assembly, Design Education

\subsection{Introduction}

Design for Manufacture as it is known today has its origins in the industrial revolution with the standardisation of parts, features and components through tolerancing (Bralla 1998).

Christopher Spencer and Ely Whitney were early pioneers of production engineering, with a focus on standardisation and inter-changeability of parts to enable the volume production of rifles (Williams and Smithurst, 2004). Henry ford is widely recognised for dividing assembly operations into short repetitive steps, using standardised parts and seeking simplification in design wherever possible. Major advances were made in the 1940s and 50s with the development of value analysis and the establishment of core design for manufacture principles. The terms producibility, manufacturability and design for assembly were introduced in the 1960s (Bralla 1998). More recently, a whole host of 'downstream' issues, 
such as design for recycling and maintenance have been addressed, under the collective banner of design for $X$ [Otto \& Wood 2001]. These issues remain as relevant today, with developments in production technology presenting new freedoms to designers (Hague 2004).

In the mid $20^{\text {th }}$ Century, the American Society of Mechanical Engineers conducted a study and concluded that mechanical engineers and designers lacked detailed knowledge on the availability, capabilities and limitations of different metal processing methods. This study resulted in a series of handbooks and guidelines that were collated in a book "Production processes: the producibility handbook” (Bolz 1947). These guidelines enabled designers to optimise components for a range of different production process. In the 1960s, these ideas began to be more formalised, with the emergence of systematic tools to enable the assessment of the manufacturability of new designs, at an assembly or system level (e.g. Boothroyd 1994) and also a component level. These guidelines were initially produced with mature production technologies in mind. Since the 1960s, many handbooks have been published that aim to provide designers with detailed information on individual production processes such as injection moulding or casting. An underlying goal of all DfM principles is to reduce the overall manufacturing cost and thus a key requirement is a clear understanding of the drivers of product cost, including the relative merits of different manufacturing processes (based on production volume) and apportionment of fixed and variable costs (Ulrich \& Eppinger 2001). DfM approaches can be applied at a component, sub-system (product or assembly) or system (product family) level. At a system level, the goal is to optimise the overall production system, reducing component count across the business (Meyer \& Utterback 1993). At a subsystem level, the goal is to optimise a sub-assembly for production (Dalgleish et al. 2000). At a component level, to aim is to optimise the manufacturing process for an individual part (Bralla 1998).

Recognising this rich history, the basic principles of effective design for assembly are well established. Work in the 1960s and 1970s by Boothroyd and Dewhurst, Lucas Engineering Systems and Ken Swift formulated some tenets of effective assembly that remain pertinent today. However, perhaps surprisingly, many designers are creating products for both low and high volume assembly without sufficient cognisance of long standing and simple ideas. One might speculate that the increased separation of design and production as a result of globally outsourced manufacture has separated many designers from the manufacturing implications of their design decisions. Many proprietary training courses and software based systems exist in order to assist a designer in 'assessing' their mechanical assemblies. Software based tools have a distinct advantage in capturing complex ideas and making them more widely available. They provide an ideal solution for individual designers to analyse or interrogate a design whilst 'on the drawing board'. However, they are less effective in group situations where dialogue and discussion are beneficial.

Recognising these limitations, [Name removed for review] (2000) generated what he called a "team based process for design for assembly" whilst teaching students at the [Location removed for review] and later [Location removed for review]. This has continued to be used in teaching design for assembly at [Location removed for review], but has recently been fully 
redesigned to provide a simplified approach. This paper describes this simplified approach and presents evidence of its use in a single industrial case study.

\subsection{Design for assembly}

The fundamentals of design for assembly were established in the 1980s (e.g. Swift 1980, Boothroyd 1983a, 1983b), refined in the 1990s (Miles \& Swift 1989, Boothroyd \& Alting 1992) and remain as relevant today as when they were first conceived. Indeed, all subsequent work exploring DfA builds on these critical elements and the techniques are well established ([Name removed for review] 2000). The fundamentals can be described in two ways; general heuristics and systematic methods.

A search for 'design for assembly' in the title of papers on academic database Scopus yields a total of 160 papers, with the earliest in 1975 by an anonymous author. A similar search within 'ScienceDirect' yields 17 responses with the earliest dating from 1983. Figure 1 demonstrates that this field is relatively small, with few academic papers, averaging around 20 per year. The lack of academic papers suggests that this is a domain in which little new is to be discovered. Indeed, many of the principles established in the 1960s and 1970s are standard content in engineering design textbooks (e.g. Ulrich and Eppinger 2000).

[Figure 1 about here]

Most early work appears in practitioner magazines, including Engineering and Machine Design. The earliest paper discusses ways in which formed metal parts might help reduce assembly costs (Anon 1975). In 1980, in Engineering magazine, Swift \& Redmond described an analysis technique to reduce a product's cost and improve design for assembly. At a similar time, Andreasen et al. $(1982,1988)$ presented a series of 'heuristic' rules or principles (Andreasen 1988, p135), which they illustrated graphically. Here, they established the importance of part reduction and simplification, and presented a range of alternative 'structural' options as the basis of building a product. Their basic argument was to first address product structure, which dominates subsequent assembly decisions, before considering the detailed design of components to ensure ease of assembly for each. They noted assembly operations of handling, composing and checking (p. 34), which incorporate specific operations including orientation, transport, connection and joining (p147). In the early 1980s, Boothroyd and Dewhurst (1983a, 1983b) widely acknowledged as key pioneers in this field, began publishing work on automated and manual assembly methods. In one article, they articulated their method for analysing designs to determine whether part count can be reduced and explored component handling and insertion to improve overall assembly time (1983a). These works and specifically Boothroyd and Dewhurst provide the basis of much subsequent thinking on design for assembly. Redford (1983) proposed an alternative systematic approach, in which a design could be assessed and classified to determine the appropriateness of manual or automated assembly. He also proposed a methodology for assessing a design, involving determining the assembly sequence, the efficiency of the design and the elimination of redundant parts. He proposed three criteria for determining whether a component is 'essential': whether there is relative movement, whether materials need to be 
different for functional purposes and whether assembly/disassembly would be impossible if they were not separate.

Warnecke (1988) and Boothroyd (1994) also described the Hitachi 'AEM method', based on quantifying a design using a set of forms containing detailed data for different assembly processes. The values calculated are used as a basis for indicating 'acceptability' and therefore prioritising redesign work. The basic logic however is similar to the methods described above: determine assembly sequence, attachment methods and then evaluate the design.

What is most notable in the output of Swift, Andreasen, Boothroyd \& Dewhurst and Redford is the broad convergence on a set of seemingly immutable principles of design for assembly. In broad terms, there are two ways in which design for assembly might be considered:

a) General DfA heuristics: these heuristics are often presented as a pair of pictures, where one presents an example of 'good practice' (e.g. assemble from above) and the other an example of 'poor practice' (e.g. assemble from multiple directions). There are many of these heuristic illustrations and principles, which are extremely easy to understand due to their graphical presentation (e.g. Andreasen et al. 1982, Pahl \& Beitz 1996). However, they are somewhat difficult to use in a design review context as there are many and it is not possible to utilise them in a systematic fashion.

b) Systematic methods for analysing assemblies: these methods present designers with a systematic way in which an assembly (either in reality or on the drawing board) might be assessed in order to identify improvement opportunities. Two specific methods dominate, both having been originated in the early 1980s (e.g. Swift 1980, 1983a, 1983b). Both of these methods follow exactly the same rationale, with a logical sequence which first aims to determine whether the overall number of components can be reduced, followed by a detailed analysis of the handling/feeding, fitting and fixing of each part. Core to these methodologies is a database of 'scores' which can be allocated to each part and assembly process in order to provide some indication of assembly complexity. These scores were developed through extensive experience of working with many firms and provide designers with a high degree of precision in scoring an individual assembly. The basic method is summarised briefly below:

- Functional analysis: is each component essential. Typically, this is based on an assessment of relative movement, need for material differences for functional purposes and the need for adjustment. If none of these are critical to functional performance, then a component can be viewed as 'non essential' and has the potential to be eliminated.

- Handling/Feeding analysis: for each part, to assess the extent to which it is difficult to physically manipulate whether by hand (handling) or with automated assembly equipment (feeding). In general, components which are very large, very small, fiddly or which might be difficult to separate are viewed as difficult to 
handle or feed. A core part of this analysis is to determine how easy it is to position a component in the right orientation, ready for assembly.

- Fixing analysis: having presented a part ready for assembly, the final step is to determine how simple it is to insert into the assembly and join to other parts. In general, fasteners which require physical manipulation are to be avoided. At this stage, any 'non-assembly' processes might be considered including reorientations, testing or setting.

These principles remain relevant and largely unchallenged. Indeed, subsequent work has focused on the inclusion of these ideas within CAD (e.g. Molloy et al. 1991), and the extension of this work to address issues such as advanced software solutions (e.g. Sanders 2009, Gui 1991), design for disassembly (e.g. Boothroyd \& Alting 1989, Cappelli et al. 2008) and design for ' $X$ ' (e.g. Kuo 2001). Indeed, soon after becoming established, these conceptually simple analysis methods have subsequently been developed as software tools for use in reviewing and conceiving designs (e.g. Scarr 1986). As software tools, they enable highly consistent and accurate results, but at the expense of accessibility. Software tools are best when used by lone designer to evaluate a design and make improvements. However, software tools tend to inhibit the involvement of wider stakeholders and important insights that might come from production engineering staff. Despite their rigour and wide applicability, there is some evidence that these more systematic methods have not been adopted as widely as would be desirable ([Name removed for review] 2000). Dalgleish (2000) also observed that there is a need to explore the ways in which DfA principles might be successfully applied and proposed a conceptual model and original piece of software to address this issue. Other authors have proposed new tools that build on these original principles, with a view to improving design at a sub assembly level (e.g. Hsu and Lin 1998).

\section{1 [Name removed for review]'s team based approach to design for assembly}

In response to these issues, [Name removed for review] (2000) developed a 'team based' approach to design for assembly, building on the fundamentals established earlier. This was developed whilst he lectured in Engineering Design at the [Location removed for review] and continued following a move to [Location removed for review].

[Name removed for review] did not challenge the basic principles outlined above, but recognised that whether dealing with heuristic guidelines or systematic approaches, there was a need to package them in a form which enables use in a team context. He named this a 'team based DfA method', known in the University, the 'post-it method'. The intended output from this exercise was a visualisation of the assembly sequence in order to identify possible improvements. The basic process had the following elements (illustrated in fig 2):

1. Disassemble an assembly and arrange the parts as an 'exploded' diagram

2. Name each of the components, writing each name on a yellow post-it note. Place the post-it note next to the relevant part. 
3. Reassemble the product, with each assembly operation noted and timed. Each assembly operation and time should be recorded on a pink post it note. On an orange post-it note, any observations or issues should be recorded (e.g. part 1 is difficult to orient). These notes are important as they contain design ideas, points of concern and areas for improvement.

4. Each of the pink post it notes should then be placed in a single row that represents the order of the assembly process. This is the first line of a 'matrix' which can then be built.

5. Underneath the pink post-it notes, the associated yellow post it notes can be added to show the components that are being assembled. Likewise, the orange notes with observations can also be added.

6. Next, each of the components is assessed to determine whether it is essential or can be eliminated. Essential parts are given a 'red dot' and non-essential a 'green dot'. On another post-it note (e.g. blue), ideas for redesign to enable the elimination of nonessential parts can be captured. These are added to the next row of the matrix.

7. A new row can be added to the matrix, which is comprises just the 'essential parts'.

8. Due to the proposed changes in components, there will be an impact on the assembly process, and this should now be reconsidered in the next row.

9. Having 'optimised' the assembly sequence, the following rows in the matrix address handling and insertion. The yellow 'component' post it notes are marked with a red ' $\mathrm{H}$ ' if they are difficult to handle, and a green ' $\mathrm{H}$ ' if they are easy. A row of potential design improvements can then be added to address the more difficult to handle parts.

10. Next, insertion processes are analysed in a similar way, with a red 'I' added to the yellow post it notes if the part is easy to insert and a green 'I' if it is difficult.

11. The last row of the matrix represents the 'final design' as a result of changes and improvements.

The process described by [Name removed for review] has been used successfully in many firms, and in the education programme at the [Location removed for review]. Its origins in the pioneering work of Boothroyd and Swift are evident, albeit presented in a more physical way. It aims to result in a product redesign which hopefully has fewer components and shorter assembly times.

However, there are a number of limitations to this method. Firstly, and most importantly, as can be seen from the set of steps described above, the process is complex. In drawing on the ideas of handling, fitting and fixing, this method loses some of the detailed granularity regarding the features which make handling complex. In laying out the assembly sequence as a single row, it assumes that there are no sub-assemblies feeding into this sequence and thus reduces the opportunity to explore how the overall assembly might be structured at a higher 
level to enable optimum assembly and line balancing. Indeed, the major failing of many approaches to design for assembly is that they treat the assembly almost in isolation from how it might actually appear on the shop floor. The unit of analysis is the 'sub-assembly' or product and the mission is to simplify it. This is necessary, but it is also important to explore how these simplifications will influence the actual production of units in practice. This is a subtle, but important point. Standard DfA software provides very strong pointers for improvement based on robust and proven principles. But, greater improvements are possible by actually analysing the production sequence, exploring bottlenecks and ensuring that the line as a whole is balanced.

[Figure 2 about here]

\subsection{A new simplified approach}

To address these limitations, the 'post-it note process' has been redesigned as described below. As with [Name removed for review]'s original method, the basic rationale of the simplified approach is built upon the foundations set out in the 1980s.

In that respect, no claims are being made for originality in terms of capturing new principles for design for assembly. Novelty is instead provided by arranging these principles in a form which is readily accessible, both in an educational and an industrial context. To achieve this, established principles are presented in an original way. For example, a set of original 'score sheets' have been developed which enable teams to consider difficulties in handling, inserting and fixing, but without needing to refer to the more complex and rigorous scoring methodologies offered by proprietary tools. These score sheets develop an idea proposed by Smith (1998) to support the teaching of design for assembly. The use of post-it notes has been retained, but they are used in a different way. Now, attention is placed on mapping the overall assembly sequence, including sub-assemblies in order to optimise overall assembly throughput. Indeed, greater attention is given to how the assembly as a manufacturing process is optimised on the shop floor in order to achieve desired production outputs. Finally, these post-it notes have been custom designed to enable ease of use (fig.3).

[Figure 3 about here]

The simplified process is designed to be followed by a small interdisciplinary team (4-6 people). In design, it is desirable to benefit from the experiences of manufacturing engineers, purchasing, maintenance, marketing and production as well as designers themselves (Whitney 1988). This approach to exploring design for assembly is most effective when it integrates these different perspectives. The ideal team size for analysis of a product is a maximum of 6 , and so if more staff are present, they can be split into a number of subgroups. This has a benefit of enabling more complex products to be analysed as sub-systems across a number of groups. Alternatively, it is possible to analyse a number of products where the assembly is simpler. In teaching the process, it is simplest when applied to an existing product. However, once the lessons are learnt, it is possible to review a design that is on the drawing board, especially if advanced prototypes are available. All applications of this process have been conducted with teams co-located at the same facility. 
The sequence of the process is described below. At each step, the associated score-sheets are also explained (figures 4-8).

\section{- Step 1 - Establish baseline metrics:}

$>$ Before beginning the process, establish some baseline metrics for expected assembly improvements. This baseline drives ideas for potential improvement and is an important step. It is also one that is often missing in established methodologies. Key metrics might include assembly cost, overall assembly time, assembly throughput and annual/monthly/weekly/daily production volumes. By focusing on these goals, it is possible to understand why improvement is needed and how existing designs might need to change in order to meet these goals.

\section{- Step 2 - disassemble:}

> Disassemble the product and place each part on the table as an 'exploded view'. A key step here is to group parts into discrete sub assemblies.

> System level analysis: before progressing to a component level analysis, make some initial judgements on the overall system in terms of design for assembly. A check list is provided to help (figure 4). Opportunities for improvement should be noted on a post-it note.

\section{- Step 3 - identify essential parts:}

$>$ Name each component by its function. This should be a verb-noun pair. If this naming is difficult, then note this as it is a strong indicator of a part with a weak 'function'. If the part is a fastener, make a note of which parts it is fastening (e.g. screw 1 to clamp parts $\mathrm{X}$ and $\mathrm{Y}$ ). Finally, sit each part on its associated post-it note. This step is very important, as by naming its function, it is possible to consider alternative ways in which this function might be delivered.

$>$ Identify essential parts: using the standard checklist (movement, material, and adjustment/replacement), determine whether the part is essential. Tick boxes are provided on the post-it t record decisions. Wherever a part is deemed 'not essential', then spend time to consider alternative ways in which the function might be achieved. Record these ideas on an 'observation or design idea' post it note.

\section{- Step 4 - reassemble:}

$>$ One person in the group should reassemble the product and another should time the operation carefully. This involves a little 'role play' where the assembler acts as they might on the assembly line. So for example, they might act the process of soldering a wire. On a 'process' post it, record each process step and the time taken. Record whether this process is a handling, fitting, fixing or feeding process. For each part, also score the difficulty of handling, fitting and fixing on the 'part' post it. See figs 5-8 for score sheets for guidance. Note, it is not intended that the scores 
are recorded numerically on the post-it note, but that the level of difficulty is captured (hard, moderate, easy).

$>$ As each 'process' post-it note is completed, lay them out to represent the actual assembly sequence. For most products, this will probably include a central production 'line' where components are sequentially added to a base or starting part. It is also likely that there will be a number of tributary lines in which subassemblies are made that then feed into the main line. Focus at this stage on the main line and sub-assembly tributaries is essential in order to estimate the potential production throughput and later to explore opportunities for improvement.

$>$ Place the 'part' post it notes directly below the associated 'process' post it notes when a new part 'enters' the assembly sequence. This gives an indication of the timing and positioning of stock on the assembly line (figure 9).

\section{- Step 5 - critique:}

$>$ Based on insights from the above analysis, critique the assembly flow overall and capture ideas for improvement and general observations. Record these on an 'observation or design idea' post-it note.

$>$ Calculate the overall assembly time by summing the individual times.

$>$ Identify the rate at which units can be delivered off the assembly line, which will be equivalent to the longest individual time in the assembly chain. Identify areas of mismatch between individual process stage times (longest and shortest) and thus areas where the assembly line is not balanced.

$>$ Calculate a maximum throughput (daily/weekly/annually). This is likely to be limited to the throughput from the single assembly station which takes the longest time.

\section{- Step 6 - redesign:}

$>$ Based on insights gained above, explore opportunities for redesign in order to achieve the desired targets set out in step one. This will include redesign to the product and redesign to the assembly process.

$>$ Use a new set of post-it notes to present the revised design and lay this out as a 'new' assembly line in order to preserve the analysis done so far.

In summary, there are six steps to the process. The post-it notes (introduced in figure 3) provide the means for capturing and presenting the analysis. The scoresheets in figures 4-8 are used as prompts to aid analysis and a typical layout might be like the one shown in figure 9. 


\subsection{The scoresheets}

The scoresheets provide a novel and simple tool to help guide the analysis. These scoresheets were created by the authors as a means of communicating concisely the core principles of DfA, an element that was missing in [Name removed for review]'s original method. The underlying content remains true to the principles first developed in the 1960s. However, the presentation of this content is seeking to be simple and immediately accessible. To do this, they use the notion of the process maturity grid (Maier et al. 2012), where performance is described in incremental steps and each score has an associated 'anchor phrase'.

For example, the element 'Open Enclosures' on the 'system' grid (figure 4) describes generic 'good' practice as "base is open with easy access all round" and poor practice as "base is enclosed and access is difficult for the whole assembly”. Two intermediate steps are then also described. This approach is appropriate where each step on the progression is distinct and provides clear indications of what improved performance might look like.

[Figure 4 about here]

[Figure 5 about here]

[Figure 6 about here]

[Figure 7 about here]

[Figure 8 about here]

[Figure 9 about here]

Scores using these grids for handling, fitting and fixing are noted on the post-it notes, as either 'easy', 'moderate' or 'difficult'. The boundary between these is left to the discretion of the team, and the exact numeric score is not treated as critical. Experience in using this approach demonstrates that this is sufficient to focus attention on the critical areas where improvement might be made.

\subsection{Case study}

This simplified approach to design for assembly has been piloted, developed and refined over a period of 3 years in an educational setting with teams of undergraduate students. During this period, the process has been followed by around 100 students, typically in groups of 6 whilst analysing an existing product. Following this period of development, the process was has subsequently been applied in a range of industrial settings, from low volume precision instruments to high volume electrical goods.

This paper reports on a case study with an Indian firm (Company X) that designs and manufactures electrical products.

\subsection{Company $X$}

Company X's products are sold internationally and the company has increased production volumes significantly over the last few years. Their interest in participation was based around 
three goals. Firstly, they aimed to improve the design for assembly of existing units in order that they might grow the annual throughput. Secondly, they sought to review designs currently on the drawing board to assess their ability to satisfy future output requirements. As a final objective, they were interested in determining whether automated assembly methods might be viable in their context.

The workshop was conducted over three days, with participants from across the technical and commercial functions of the business. In total, 22 members of staff took part in the workshop. For all exercises, the large group was split into smaller teams which each included mechanical, electrical and production engineers as well as assembly and commercial personnel. A significant part of the workshop was in repeating the simplified DfA process over two cycles, with the intention of reinforcing the core lessons and encouraging 'doubleloop' learning (Argyris and Schon, 1978). The first cycle considered the design of an existing product, and the second cycle the design of a future product. In between, participants observed assembly practices first hand in order to compare their analysis against real manufacturing practices. Again, this helped in reinforcing the core lessons. An additional cycle was also included in which the teams disassembled and reassembled electric power tools produced by a major international brand. Again, this served to reinforce the principles, but is not reported here.

On day 1, existing products were analysed using the process outlined above. This was done in meeting rooms, with 5 teams producing independent analysis for discussion. Teams were tasked with identifying short, medium and long term improvement opportunities. On day 2, the group analysed the actual assembly, on the shop floor, of the same products analysed on day 1. Participants remained in the 5 pre-allocated teams and each team was tasked with timing individual assembly operations, identifying assembly difficulties and looking more widely at the organisational system around the assembly operations (e.g. parts supply, testing etc). Following this analysis, teams then explored potential design improvements that might have a short, medium or long term impact. These were compared against those identified on the day 1 . On day 3 , the group analysed a product currently in development. This product was at an advanced prototype stage, enabling its disassembly, reassembly and analysis as outlined in the process described above. However, it had not yet been launched to production. The focus of this analysis was to determine whether the proposed design could be produced in the expected annual volumes and if not, how it might be redesigned. Again, the same process was followed and opportunities for design improvement were noted. Outputs from each of these stages will now be summarised.

Each of these three tasks will now be described in more detail, with the two cycles of 'desk analysis presented in line with the process described in section 3.

\subsection{Exercise 1: desk analysis of existing products}

For this first exercise, the participants followed the simplified DfA process from steps 1 to 5 , and whilst design ideas were captured, they did not at this stage engage in a full redesign exercise. 
The 5 teams were each given one of two products to analyse. To protect the firm commercially, these have been labelled product ' $A$ ' and product ' $B$ '. Teams followed the sixstep method described above: establish metrics, disassembly, identify essential parts, reassembly, critique and redesign. Table 1 summarises some of the key observations made as a result of this analysis.

- Step 1 - Establish baseline metrics: The core baseline metric was a desire to increase production volumes by a factor of ten, from 200,000 units per annum to 2 million units per annum.

- Step 2 - disassemble: Products A and B were disassembled and laid out as an 'exploded' view.

- Step 3 - identify essential parts: Both products were analysed to explore possibilities for removal of non-essential components. Three teams analysed product A and the number of non-essential parts varied from 17 to 24 out of approximately 30. For product B, around 35 out of 65 parts were viewed as non-essential. Variations in analysis are to be expected, and reflect the fact that these judgements are often highly subjective, even when guided (figure 10).

- Step 4- reassemble: Product A took around 30 minutes to reassemble, whilst product $\mathrm{B}$, despite having more components took around 10 minutes. Each individual assembly process was analysed for handling, fitting and fixing (figures 11 and 12). The score-sheets were used as a guide to determine whether handling, fitting and feeding for each part is hard, moderate or easy.

- Step 5 - critique: The most immediate opportunities for improvement lied in component simplification, as well as the removal and simplification of fasteners. Soldered wires created significant difficulties. Teams analysing both products saw potential to reduce overall assembly time by around $50 \%$.

[Figure 10 about here]

[Figure 11 about here]

[Table 1 about here]

\subsection{Exercise 2: shop floor analysis of existing products}

Having analysed the products in isolation, the groups then investigated the assembly of their product in reality. Here, the intention was to explore the extent to which the real assembly process reflected their 'idealised' models produced in exercise 1. Thus, the simplified DfA process was not explicitly followed during this exercise, but participants were encouraged to compare the reality against their own judgements in disassembling and reassembling the products.

The whole group was split into two, in order that every aspect of the assembly for each product could be assessed. The two teams were tasked with observing every assembly station, 
recording the assembly time and noting any issues. They were specifically asked to note any handling, fitting and feeding issues as well as any other aspects of poor design for assembly. After this observation, the teams collated their results in order to identify short, medium and long term opportunities for improving the assembly lines. This might include process changes as well as changes to the design of the product. Results are summarised in table 2.

We see a distinct difference in the total assembly times measured: in reality, product A took 13 minutes per unit, as compared with approximately 30 minutes in the desk analysis. Product B took 8 minutes in reality compared with 10 minutes in the desk analysis. However, these differences are not unexpected, and one would expect the shop floor operation to be more efficient. In completing this analysis, designers were able to observe the ways in which assembly operators tackled difficult assembly operations.

Perhaps the greatest surprise however is the range of 'takt' times for each assembly station. For product $\mathrm{A}$, this ranged from $15-50$ seconds, and product $\mathrm{B}$, the range was $10-70$. The assembly line overall can go no more quickly than the slowest takt time. Thus, across the whole assembly process, there was a significant portion of non-value added time and as a result, operators not been utilised efficiently. This difference in the timing of each assembly operation is highly significant and was not so visible in the desk analysis. The maximum takttimes also set the likely annual production volume at about 100,000 units per annum. Thus, production volumes could only be increased by either significant design changes or additional assembly resources. During the shop floor analysis, it was less easy to identify parts that might be eliminated, but challenges in handling, fitting and fixing were more visible. This was especially the case for wiring and soldering, where the assembly was reoriented many times at each assembly station.

As a result of this exercise, a number of short, medium and long term improvement opportunities were noted, both for the assembly process and for the product designs.

[Table 2 about here]

\subsection{Exercise 3: analysis of product in development}

The final exercise was to use the principles learnt to analyse a product which is currently on the drawing board. Having gained experience in the use of the simplified DfA process, this final analysis sought to analyse the potential of this new product for meeting the stretching target established in the first exercise. As before, the participants followed the simplified DfA process from steps 1 to 5 , to conclude with a series of concrete proposals for design improvement:

- Step 1 - Establish baseline metrics: This product was the 'next generation' product, hoped to enable the transition from 100,000 units per annum to 2 million units per annum. The growth in production volumes represents a ten-fold increase in current production. Significantly, it demands that the operations produce approximately 1 unit every ten seconds, (assuming a single production line). Thus, the longest individual takt time for any assembly station must not exceed 10 seconds, assuming only one 
station per assembly operation. Notably, this critical issue had not been considered by the design team at any stage during the concept design work.

- Step 2 - disassemble: The system level analysis confirmed the need to provide greater attention to the creation of a 'chassis' as a stable base for the whole assembly. This core 'system level' issue had not previously been considered. As a result, the product required multiple re-orientations.

- $\quad$ Step 3 - identify essential parts: In total, the new product contained 45 parts, but 18 of these were considered to be non essential. This included a large number of screws and fixings that could easily be designed out.

- Step 4- reassemble: A number of parts were identified as being 'low scorers' for handling, fitting and feeding. The worst offenders combined difficult orientation with fiddly handling and poor accessibility.

- Step 5 - critique: Without any design changes, it was estimated that in order to produce the desired quantity, 48 assembly stations would be needed. This would include a 5 step main line, two tributary lines and multiple lines operating in parallel. With the assumption that all possible design changes were implemented, then it is believed that the assembly could be completed with 16 workstations. This includes 12 main processing stages, with parallel activity at two of those stages. Potentially 1 or 2 tributary sub-assemblies might reduce this further. In order to achieve this simplification in the assembly sequence, a number of significant design changes would be needed. Specifically, the proposed design included 45 discrete parts of which 18 could be judged as non-essential. Several of the components scored particularly lowly for handling, due to tangling and delicacy and redesign would help. Several assembly operations were viewed as fiddly, and the overall assembly logic did not facilitate a logical flow of parts onto a common base. Indeed, simple re-design would ensure that the base component could travel on a fixture and require no reorientation during production. Greater use of snap-fits, and better use of location features in the injection mouldings would simplify assembly and reduce errors. In addition, the number of screw fixtures could be reduced.

It was concluded that with substantive re-design before commencing production, it would be possible to meet the desired production targets of 2 million units per annum.

\subsection{Discussion and conclusions}

This paper has presented a new and simplified approach to design for assembly, which builds on prior work. This contribution is thus incremental, in that it is taking existing knowledge and re-packaging it in order to broaden its uptake and application. However, this does not mean that it is insignificant or unimportant. Indeed, if anything, this contribution is timely, as increased separation of production from design is arguably resulting in a gradual corrosion these long established good practices. It is evident through application in both education and industrial settings that junior designers are not aware of many of these important basics. 
Thus, this tool is seeking to communicate some critical design messages in a structured, concise and compelling way that is suitable for use in a team setting.

This new approach has been developed and refined in an educational context and has been demonstrated as producing significant results in an industrial case study, both for existing products and products which are currently at a design stage. Through application of this process, the design team identified a significant number of potential design changes that together would enable a growth in throughput by a factor of ten.

The tool as described is based around established design for assembly principles and demonstrates their lasting relevance. However, by presenting these principles in a simplified way, it is hoped that this tool might help broaden the use of these ideas. In particular, the simplified process is an advancement of an existing process originally developed by [Name removed for review] et al. (2000). This redesign makes a number of notable contributions:

- The new process utilises a set of 5 simplified 'score sheets' which embody the characteristics of effective handling, fitting and fixing. These simple score sheets lack the fine 'resolution' of software based methods, but enable the basic ideas to be grasped quickly and efficiently in a group setting. By presenting these score sheets as a maturity grid, targets for improved design can be easily seen. The addition of a system level score-sheet is also an improvement to existing approaches.

- The process aims to make a stronger link between the logical assembly structure of the product and the actual design of the assembly line as a result. Indeed, it is this conceptual change which provided most useful in the case study, where annual production volumes are used as a primary driver, rather than individual component count or overall assembly time. With this driver in mind, it is the time of individual assembly operations which becomes much more critical.

- The attention given to creating a 'simulation' of the real assembly sequence is significant, and enables participants to clearly identify potential assembly bottlenecks and issues.

In the case study, the simplified DfA tool was used twice, firstly on an existing product and secondly on a product in development. In between, the team spent time on the shop floor to experience the challenges of assembling the existing product in reality. The coupling of a 'desk' analysis with observation of the real thing was very significant in helping the team to fully understand the implications of design decisions on ease of assembly. Insights were generated that would not have come from a desk analysis on its own. For example, one component was scored as being comparatively easy to handle in the initial analysis. However, when seen on the shop floor, it was evident that the operator had to turn around to collect this part from a large tray placed behind them.

Thus, the 'desk' analysis enabled the basic principles to be quickly understood. By following this with an observation of the real production process, participants were much better attuned to the critical issues which they might observe. The comparison between the two yielded 
further opportunities for improvements to the design and also the assembly line. Finally, having gained this experience, the team was in the right frame of mind to tackle the detailed and potentially 'brutal' review of a design which is currently on the drawing board.

The case study demonstrates the significant importance of involving a multi-functional team in any DfA exercise. The different perspectives, as noted by Whitney (1988, p85) enable a complete analysis, as each brings complementary expertise. This is a benefit that is not delivered through software based systems which are typically administered by the design engineer or at best a small team of engineers. The post-it note based approach brings the analysis away from the computer screen and by encouraging the whole assembly to be visualised, enables staff with different levels of design expertise to participate actively.

This highly visual approach to exploring the assembly has resonances with other design techniques which seek to make the intangible more accessible. Tools such as Quality Function Deployment, Design Structure Matrices (DSM) and Value Analysis similarly seek to encourage wider participation and discussion regarding specific design issues. DSM in particular have recently been proven useful as a visualisation tool for exploring dependencies and especially for determining task sequence once dependencies have been determined. This ability to visualise dependencies has been applied for modelling interactions among components, tasks and communications (e.g. Browning 2001, Eppinger and Browning 2012). Researchers have also used DSM approaches to determine modular design and design for assembly in distributed manufacturing systems (Farid and McFarlane 2006) and timber construction (Björnfota and Stehna 2007). Thus, DSM based tools might be beneficially applied following this simplified team based process for DfA, once the overall assembly 'direction' has been jointly generated and agreed. Indeed, this type of team based process might valuably be considered as a pre-cursor to more analytical (software based) approaches and simulations.

The basic principles of design for assembly remain uncontested and it is arguably widely assumed that design engineers are knowledgeable in this area. However, anecdotal experience from many firms suggests that this is not the case. Engineers face a competing set of requirements and often, issues such as design for assembly take second place behind the primary objectives of meeting performance or market requirements. For many engineers, the existing approaches to analysis are useful, but they perhaps overly emphasise the 'scores' as opposed to the overall assembly logic. The simplified approach described in this paper seeks to encourage engineers to consider their design decisions in the context of the overall assembly flow and the implications this might have on the production system. This wider perspective makes a valuable contribution to this field.

\subsection{Opportunities for further work}

This paper presents the application of this new process in just one firm. Whilst it has been used in other industries, a wider cross-industry comparison of design for assembly would potentially be valuable to explore the different challenges and issues faced in different sectors. 
This paper does not seek to claim that this new process is 'better' than previous methods, but that it is designed explicitly with team interaction in mind. However, a direct comparison of this new process against standard DfA software might highlight some interesting issues.

This paper describes the identification of possible design improvements to an existing product and also a product on the drawing board. It would be interesting to re-visit the case study in order to explore the extent to which the proposed improvements to both products and processes were implemented and the difficulties encountered.

In applying this process, we notice that many (especially junior) designers have little awareness of how their design decisions influence the wider production system. This would appear to be a step backwards compared with the steps made through the final 20 years of the $20^{\text {th }}$ Century. A possible explanation might be the growing geographical separation between much design and production as manufacturing is outsourced to low wage regions; poor design decisions have less impact when wage-rates are low. However, as firms increasingly see the need to repatriate production, poor design for assembly can have a significant effect. This is of course speculation and thus a wider study of awareness, knowledge and skill in design for manufacture might be highly informative. Given this broad observation, the time is ripe for new thinking, tools and methods of bridging this knowledge gap.

\subsection{References}

Andreasen M M, Kahler S, Lund T, (1982), Design for assembly - an integrated approach, Assembly Automation, Vol. 2 Iss. 3, pp 141-145

Anon, (1975), Design for assembly, Precis Met, 33 (7), pp. 26-28

Argyris, C. \& Schon, D. (1978) Organisational learning, Addison Wesley, Reading, MA. REFERENCE REMOVED FOR REVIEW

Björnfota A, Stehna L, 2007, A design structural matrix approach displaying structural and assembly requirements in construction: a timber case study, Journal of Engineering Design, Vol. 18 No. 2, pp113-124

Bolz R W, (1947), Production Processes: Their Influence on Design, Penton

Boothroyd G, Alting L, (1992), Design for assembly and disassembly, Keynote paper, Annals of the CIRP - manufacturing technology, Vol. 41, No. 2, pp 625-636

Boothroyd G, Alting, L, (1989), Design for assembly and disassembly, Annals of the CIRP Manufacturing Technology, Vol. 40 No. 1, pp1-4

Boothroyd G, Dewhurst P, (1983a), DESIGN FOR ASSEMBLY: SELECTING THE RIGHT METHOD, Machine Design , Volume 55, Issue 25, 1 January 1983, Pages $94-98$

Boothroyd G, Dewhurst P, (1983b), DESIGN FOR ASSEMBLY: MANUAL ASSEMBLY, Machine Design , Volume 55, Issue 28, 8 December 1983, Pages 140-145

Boothroyd G,(1994), Product design for manufacture and assembly, Computer-Aided Design 26(7, pp505-520.

Bralla J, (1998), Design for manufacturability handbook 2nd edition, McGraw Hill

Browning T R, (2001), Applying the design structure matrix to system decomposition and integration problems: a review and new directions, IEEE Transactions on Engineering Management, Vol. 48 No. 3, pp292-306 
Cappelli F., Delogu M., Pierini M., Schiavone F., 2007. Design for disassembly: a methodology for identifying the optimal disassembly sequence, Journal of Engineering Design, 19 (6), pp 563-575

Dalgliesh G F, Jared J E M, Swift K G, (2000), Design for assembly: influencing the design process, Journal of Engineering Design, Vol. 11 No.1, pp 17-29

Eppinger S D, Browning T, (2012), Design Structure Matrix Methods and Applications (Engineering Systems), The MIT Press, USA

Farid A, McFarlane D C, (2006), An Approach to the Application of the Design Structure Matrix for Assessing Reconfigurability of Distributed Manufacturing Systems, IEEE Workshop on Distributed Intelligent Systems: Collective Intelligence and Its Applications

Gui J K., 1991, Object-oriented assembly and assembly design process modelling, Journal of Engineering Design, 2 (2), pp141-149

Hague R, Mansour S, (2004), Material and design considerations for rapid manufacturing, International Journal of Production Research 42(22), pp4691 - 4708

Hsu Hung-Yao, Lin G C I, 1998, A design for assembly based product redesign approach, Journal of Engineering Design, 9 (2), pp 171-195

Kou T-C, Huang S H, Zhang H-C, (2001), Design for manufacture and design for ' $\mathrm{X}$ ': concepts applications and perspectives, Computers and industrial engineering, Vol. 41, pp 241-260

Maier A, Moultrie J, Clarkson P J, (2012), Assessing organisational capabilities: reviewing and guiding the development of maturity grids, Journal of IEEE Transactions in Engineering Management, Vol. 59 No. 1, pp 138-159

Meyer M H, Utterback J M, (1993), The product family and the dynamics of core capability, Sloan Management Review, Vol. 34 No. 3, p29

Miles B, Swift K G, (1998), Design for manufacture and assembly, Manufacturing Engineer, Vol. Vol. 77 No. 5, pp 221-224

Molloy E, Yang H, Browne J, (1991), Design for assembly with concurrent engineering, Annals of the CIRP, Vol. 40 No.1

Otto K, Wood K, (2001), Product design: techniques in reverse engineering and new product development, Prentice Hall, USA

Pahl G, Beitz W, (1996), Engineering design: a systematic approach, Second edition, Springer-Verlag, Berlin

Redford A H, (1983), Design for assembly, Design Studies, Volume 4, Issue 3, July 1983, Pages 170-176

Sanders D, Tan Y C, Rogers I, Tewkesbury G E, (2009), An expert system for automatic design for assembly, Assembly Automation, Vol. 29 Iss. 4, pp 378-388

Scarr A J, (1986), Product design for automated manufacture and assembly, Annals of the CIRP, Vol. 35 No. 1

Smith R P, (1998), Teaching design for assembly using product disassembly, IEEE Transactions on Education, Vol. 41 No. 1

Swift K, Redford A H, (1980), Design for Assembly, Engineering, Vol. 220 Iss. 7, pp 799802 
Tavakoli M S, Mariappan J, Huang J, (2003), Design for assembly versus design for disassembly: a comparison of guidelines, ASME International Mechanical Engineering Congress, Washington

Ulrich K T, Eppinger S D, (2000), Product design and development, McGraw-Hill, USA

Warnecke H J, Bassler R, (1998), Design for assembly: part of the design process, Annals of the CIRP, Vol. 37 No. 1

Williams D., Smithurst P., (2004), Christopher Spencer: the manufacturing technology of his repeating rifle, Arms \& Armour, 1 (2), pp 165-182

Whitney D E, (1988), Manufacturing by Design, Harvard Business Review, July-August

Whitney D E, (2004), Mechanical assemblies: their design, manufacture and role in product development, Oxford University Press, UK 


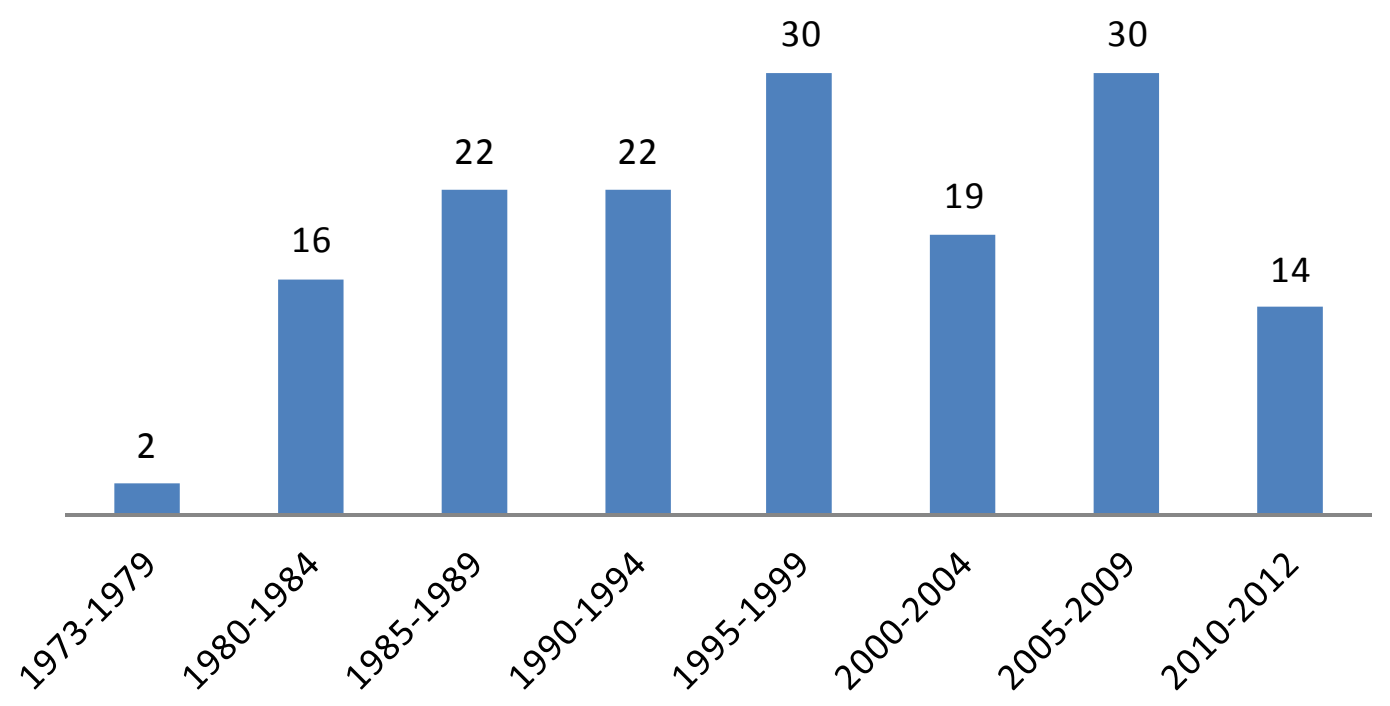

Figure 1: Number of papers containing 'Design for Assembly' within the title on Scopus database 1973-2012 


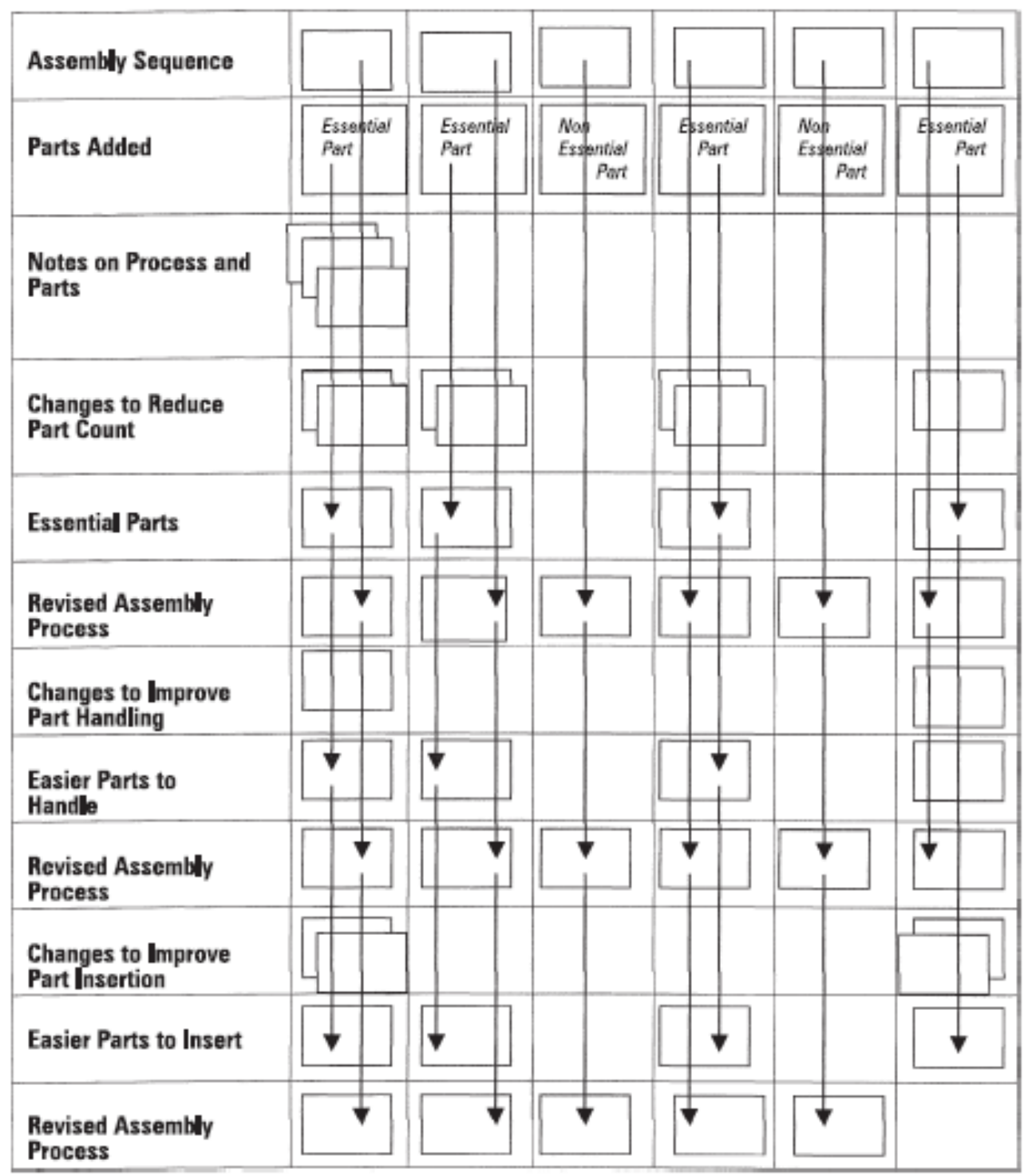

Fig 2: [Name removed for review]'s team based approach 


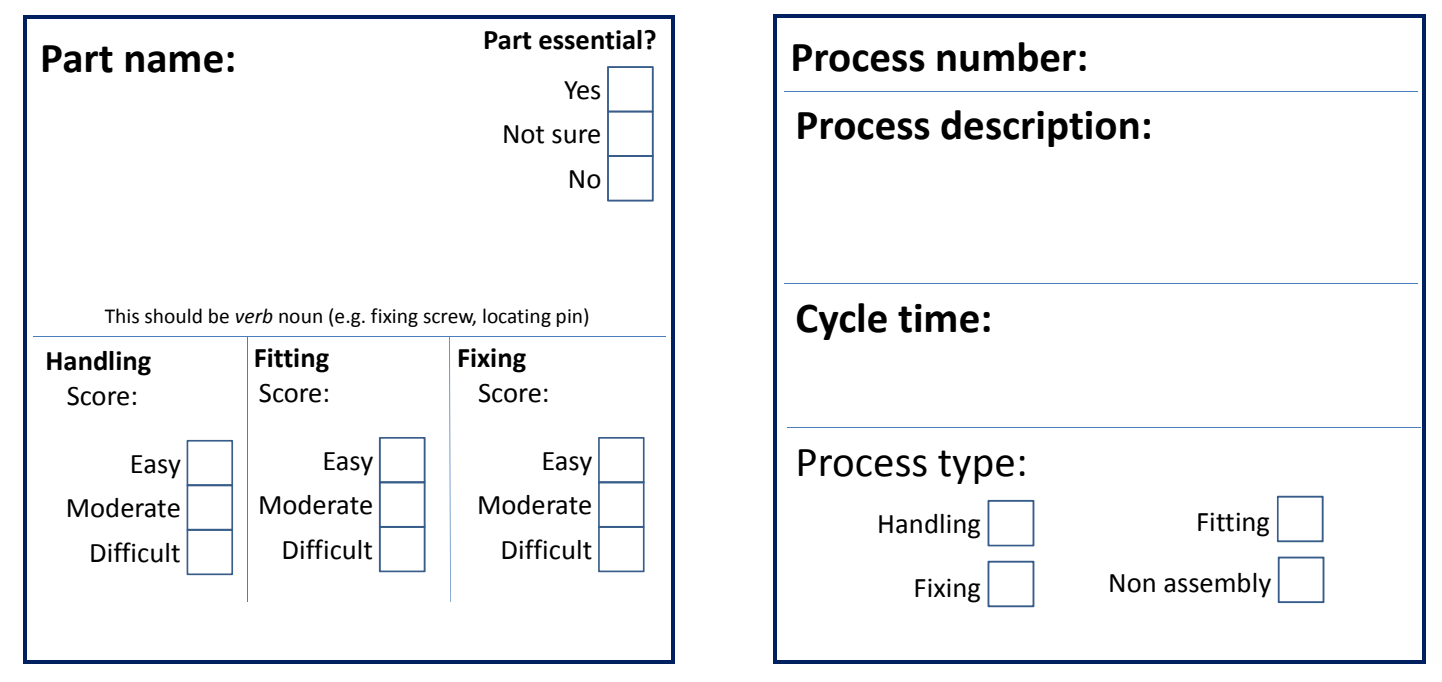

\section{Observation or design idea}

Fig 3: Custom designed post-it notes 
Good

0
OK

1

\begin{tabular}{|c|c|c|c|c|c|}
\hline $\begin{array}{l}\text { Stable base for } \\
\text { assembly }\end{array}$ & $\begin{array}{l}\text { A single base } \\
\text { which needs no } \\
\text { reorientation } \\
\text { during assembly }\end{array}$ & $\begin{array}{l}\text { A single base } \\
\text { which requires } \\
\text { some reorientation } \\
\text { during assembly }\end{array}$ & $\begin{array}{c}\text { Some core parts } \\
\text { onto which many } \\
\text { sub-assemblies are } \\
\text { joined }\end{array}$ & $\begin{array}{l}\text { A complex set of } \\
\text { sub-assemblies } \\
\text { with no single base }\end{array}$ & \\
\hline Assembly directions & $\begin{array}{l}\text { All parts delivered } \\
\text { from above }\end{array}$ & $\begin{array}{l}\text { Most parts } \\
\text { delivered from } \\
\text { above }\end{array}$ & $\begin{array}{l}\text { Some parts } \\
\text { delivered from } \\
\text { above }\end{array}$ & $\begin{array}{l}\text { Parts delivered } \\
\text { from all directions }\end{array}$ & \\
\hline Open enclosures & $\begin{array}{l}\text { Base is open with } \\
\text { easy access all } \\
\text { round }\end{array}$ & $\begin{array}{l}\text { Base is partially } \\
\text { open, but generally } \\
\text { good access }\end{array}$ & $\begin{array}{l}\text { Base is not open, } \\
\text { but access is } \\
\text { generally good }\end{array}$ & $\begin{array}{l}\text { Base is enclosed } \\
\text { and access is } \\
\text { difficult for the } \\
\text { whole assembly }\end{array}$ & \\
\hline Wiring & $\begin{array}{l}\text { No loose wiring or } \\
\text { soldering needed }\end{array}$ & $\begin{array}{l}\text { Some loose wiring. } \\
\text { Locating and fixing } \\
\text { features provided }\end{array}$ & $\begin{array}{l}\text { Tricky connections } \\
\text { for wiring, but } \\
\text { wiring paths well } \\
\text { organised }\end{array}$ & $\begin{array}{l}\text { Wiring paths not } \\
\text { well planned, no } \\
\text { location and many } \\
\text { soldered joints }\end{array}$ & \\
\hline \multirow[t]{2}{*}{ Fasteners } & $\begin{array}{l}\text { Minimal fasteners, } \\
\text { components self } \\
\text { locating and fixing }\end{array}$ & $\begin{array}{l}\text { Some fasteners, } \\
\text { but standardised } \\
\text { sizes }\end{array}$ & $\begin{array}{l}\text { Lots of fasteners, } \\
\text { with some } \\
\text { standardisation }\end{array}$ & $\begin{array}{c}\text { Many different } \\
\text { types of fastener } \\
\text { with no } \\
\text { standardisation }\end{array}$ & \\
\hline & & & & $\begin{array}{l}\text { TOTAL SYSTEM } \\
\text { SCORE }\end{array}$ & \\
\hline
\end{tabular}

Fig 4: Score sheet for the system

0

\begin{tabular}{|c|c|c|c|c|}
\hline $\begin{array}{c}\text { Component size } \& \\
\text { weight }\end{array}$ & $\begin{array}{l}\text { Convenient size } \\
\text { One hand only }\end{array}$ & $\begin{array}{l}\text { Small } \\
\text { Fiddly or requires } \\
\text { tools }\end{array}$ & $\begin{array}{l}\text { Large / heavy } \\
2 \text { hands or tools }\end{array}$ & $\begin{array}{l}\text { Very large / heavy } \\
2 \text { people or hoist }\end{array}$ \\
\hline Handling difficulties & $\begin{array}{l}\text { No handling } \\
\text { difficulties }\end{array}$ & $\begin{array}{c}\text { Need care to grip } \\
\text { Adherence, delicate, } \\
\text { sharp / abrasive }\end{array}$ & $\begin{array}{l}\text { Difficult to grip } \\
\text { Flexible, } \\
\text { untouchable, } \\
\text { awkward }\end{array}$ & $\begin{array}{c}\text { Tangling \& severe } \\
\text { nesting }\end{array}$ \\
\hline $\begin{array}{c}\text { Beta (rotational) } \\
\text { symmetry: } \\
\text { about axis of insertion }\end{array}$ & Any orientation & $\begin{array}{c}\text { Easy to orient: } \\
\text { orientation easy to } \\
\text { see and mistake } \\
\text { proof }\end{array}$ & $\begin{array}{l}\text { Tricky to orient: } \\
\text { Orientation difficult } \\
\text { to see but mistake } \\
\text { proof }\end{array}$ & $\begin{array}{l}\text { Difficult to orient: } \\
\text { Orientation difficult } \\
\text { to see - mistakes } \\
\text { possible }\end{array}$ \\
\hline & & & & $\begin{array}{l}\text { TOTAL HANDLING } \\
\text { SCORE }\end{array}$ \\
\hline
\end{tabular}

Fig 5: Score sheet for component handling 


\begin{tabular}{|c|c|c|c|c|c|}
\hline & 0 & 1 & 3 & 5 & Score \\
\hline $\begin{array}{l}\text { Gripping / holding } \\
\text { during insertion }\end{array}$ & $\begin{array}{l}\text { Holding simple } \\
\text { during insertion - } \\
\text { no tools needed }\end{array}$ & $\begin{array}{l}\text { Need tools to grip } \\
\text { during insertion - } \\
\text { but simple }\end{array}$ & $\begin{array}{l}\text { Difficult to hold } \\
\text { securely during } \\
\text { insertion }\end{array}$ & $\begin{array}{c}\text { No suitable / easy } \\
\text { to access gripping } \\
\text { surfaces during } \\
\text { insertion }\end{array}$ & \\
\hline Holding down & \multicolumn{3}{|c|}{ Self sustaining - stays in place without holding down } & $\begin{array}{c}\text { Needs holding in } \\
\text { place - secured } \\
\text { later }\end{array}$ & \\
\hline View during insertion & $\begin{array}{l}\text { Clear view during } \\
\text { insertion }\end{array}$ & $\begin{array}{c}\text { View partly } \\
\text { obscured during } \\
\text { insertion }\end{array}$ & $\begin{array}{l}\text { View badly } \\
\text { obscured during } \\
\text { insertion }\end{array}$ & $\begin{array}{c}\text { No view during } \\
\text { insertion - feel only }\end{array}$ & \\
\hline Access & $\begin{array}{l}\text { Clear access } \\
\text { during insertion }\end{array}$ & $\begin{array}{l}\text { Partly obscured } \\
\text { access during } \\
\text { insertion }\end{array}$ & $\begin{array}{l}\text { Badly obscured } \\
\text { access during } \\
\text { insertion }\end{array}$ & No access to insert & \\
\hline Insertion direction & $\begin{array}{l}\text { Straight line from } \\
\text { above }\end{array}$ & $\begin{array}{l}\text { Straight line, from } \\
\text { side }\end{array}$ & $\begin{array}{l}\text { Straight line from } \\
\text { below }\end{array}$ & $\begin{array}{l}\text { Not in a straight } \\
\text { line }\end{array}$ & \\
\hline \multirow[t]{2}{*}{ Insertion resistance } & No resistance & Light resistance & $\begin{array}{l}\text { Significant } \\
\text { resistance }\end{array}$ & $\begin{array}{l}\text { Large resistance - } \\
\text { need leverage }\end{array}$ & \\
\hline & & & & $\begin{array}{l}\text { TOTAL INSERTION } \\
\text { SCORE }\end{array}$ & \\
\hline
\end{tabular}

Fig 6: Score sheet for component insertion or fitting
0
1
3
5

\begin{tabular}{|c|c|c|c|c|}
\hline Threaded fasteners & No threaded fasteners & $\begin{array}{c}\text { Self drilling/ tapping } \\
\text { screws }\end{array}$ & $\begin{array}{c}\text { Stud / bolt \& nut } \\
\text { Screw }\end{array}$ & $\begin{array}{c}\text { Nut, bolt \& washer } \\
\text { (separate loose parts) }\end{array}$ \\
\hline $\begin{array}{c}\text { Non-threaded } \\
\text { fasteners }\end{array}$ & $\begin{array}{c}\text { Snap fit or light push } \\
\text { fit }\end{array}$ & Rivet & $\begin{array}{c}\text { Simple crimping or } \\
\text { bending }\end{array}$ & $\begin{array}{c}\text { Difficult crimping or } \\
\text { bending }\end{array}$ \\
\hline $\begin{array}{c}\text { Soldered / Welded } \\
\text { joints }\end{array}$ & No welded joints & Simple solder/ weld & Difficult weld \\
\hline Glued joints & No glued joints & Simple glued joint & Difficult glued joint \\
\hline
\end{tabular}

Fig 7: Score sheet for component fixing 
0

\begin{tabular}{|c|c|c|c|}
\hline Additional screwing & No threaded fasteners & $\begin{array}{c}\text { Some additional } \\
\text { screwing }\end{array}$ & $\begin{array}{c}\text { Significant additional } \\
\text { screwing }\end{array}$ \\
\hline Setting & No setting required & Simple / quick setting & $\begin{array}{c}\text { Complex / slow } \\
\text { setting }\end{array}$ \\
\hline Test \& measure & No testing \& measuring & Easy / quick testing & Difficult/ slow testing \\
\hline Fill / empty & No filling / emptying & $\begin{array}{c}\text { Simple / quick fill/ } \\
\text { empty liquid / gas }\end{array}$ & $\begin{array}{c}\text { Complex / slow fill/ } \\
\text { empty gas }\end{array}$ \\
\hline Re-orientation & No reorientation & Small reorientation & $\begin{array}{c}\text { Significant } \\
\text { reorientation }\end{array}$ \\
\hline
\end{tabular}

Fig 8: score sheet for non-assembly processes

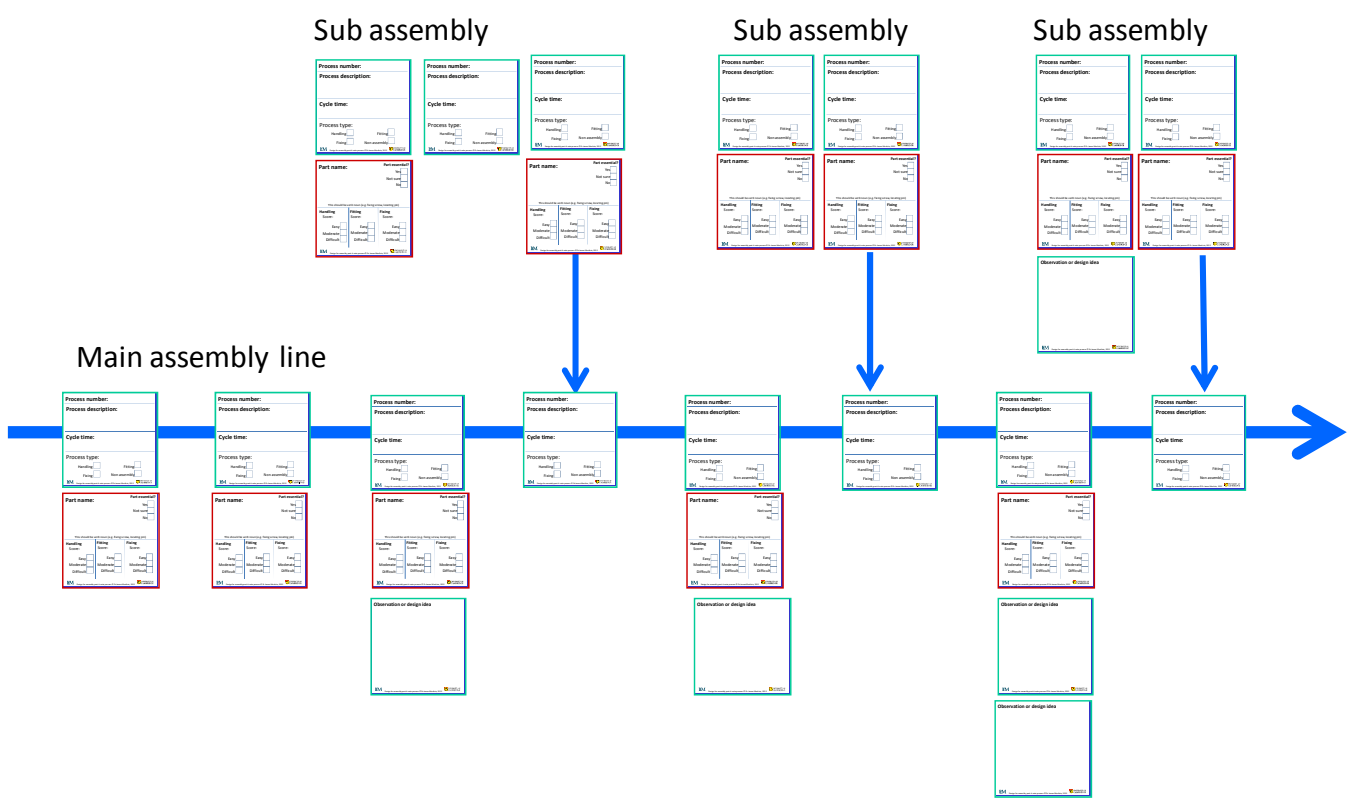

Fig 9: A typical layout of post-it notes for an assembly analysis 


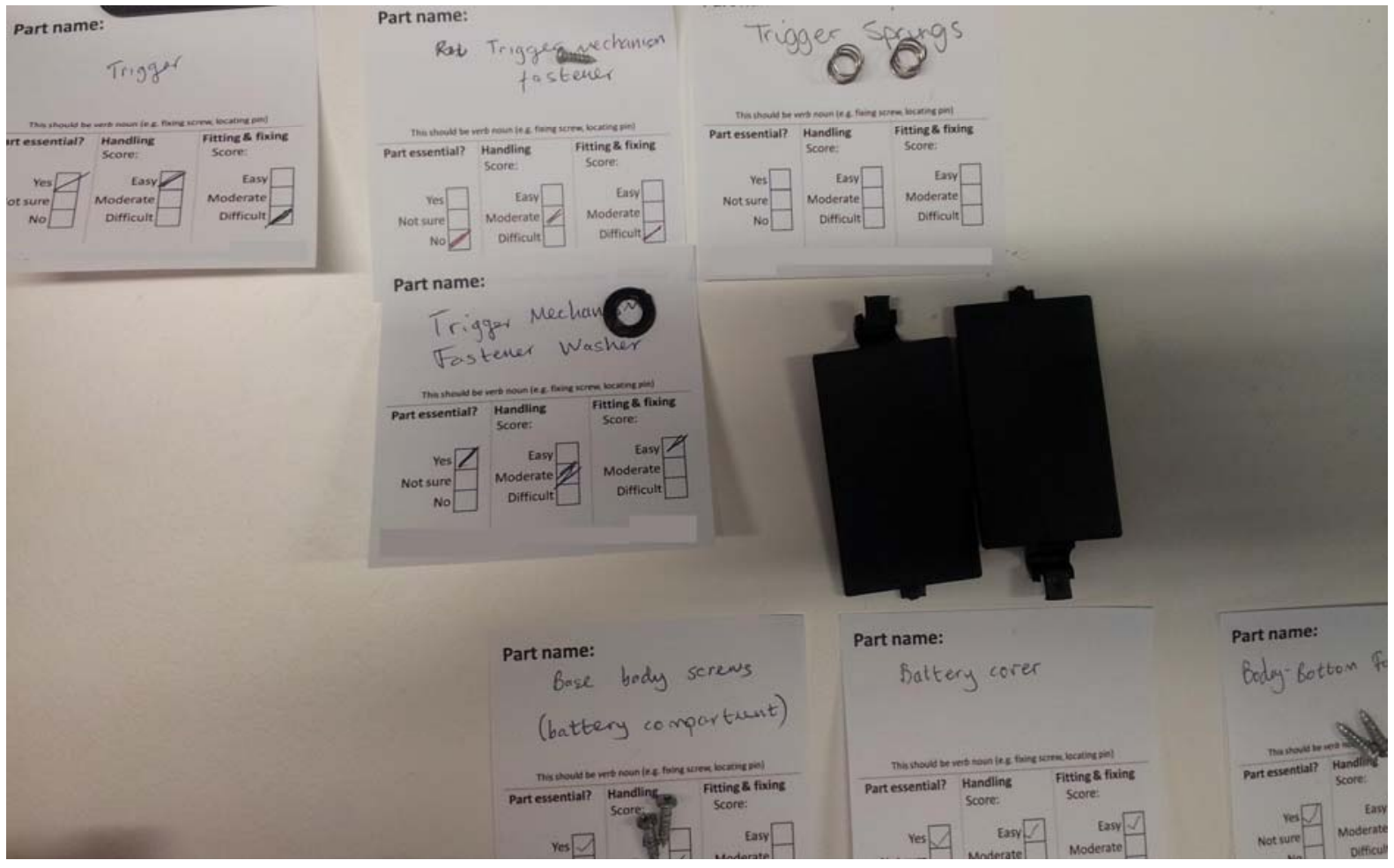

Fig 10: Photograph showing a close up of the post-it notes in use

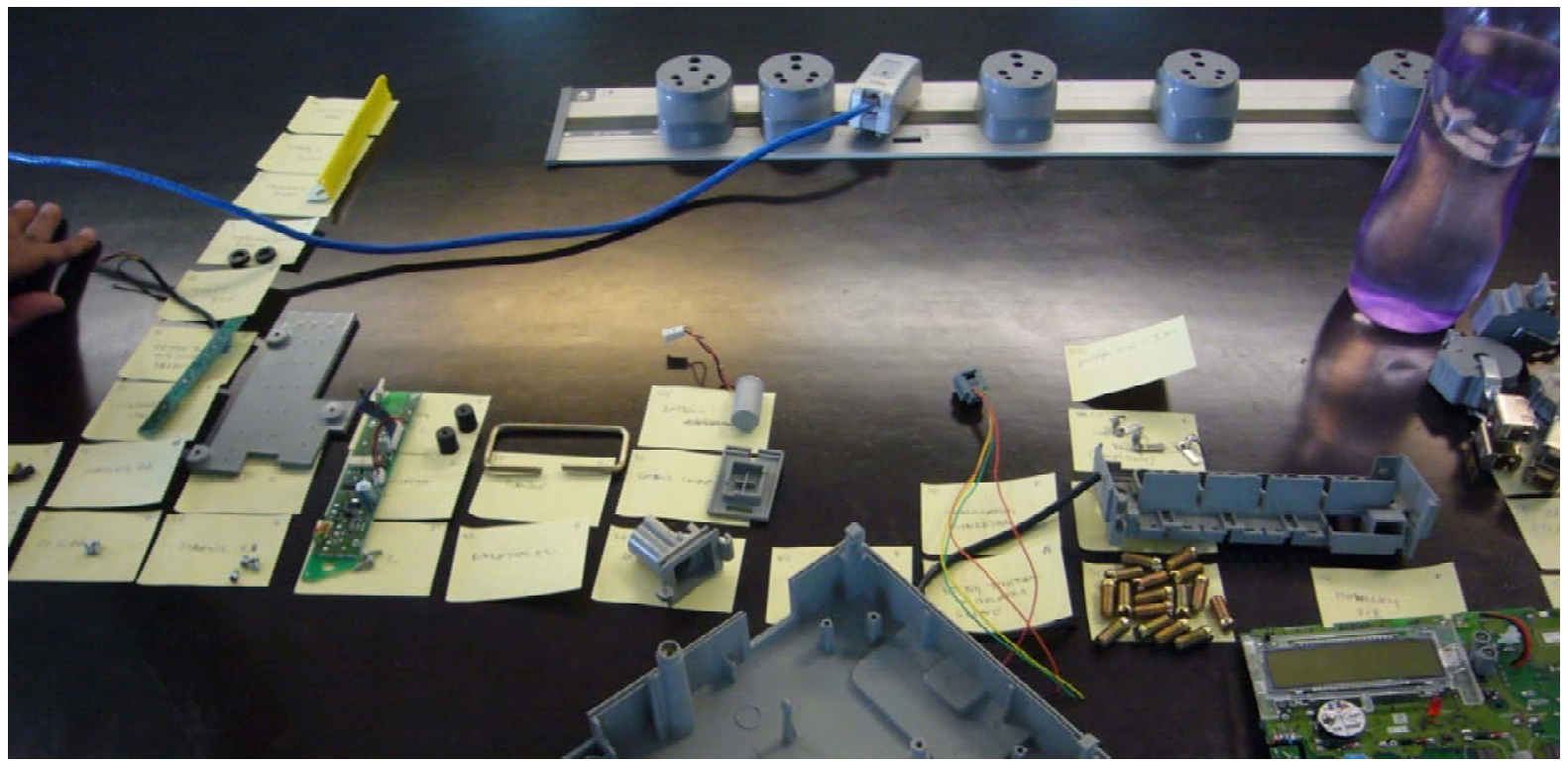

Fig 11: Photograph showing the DfA process 


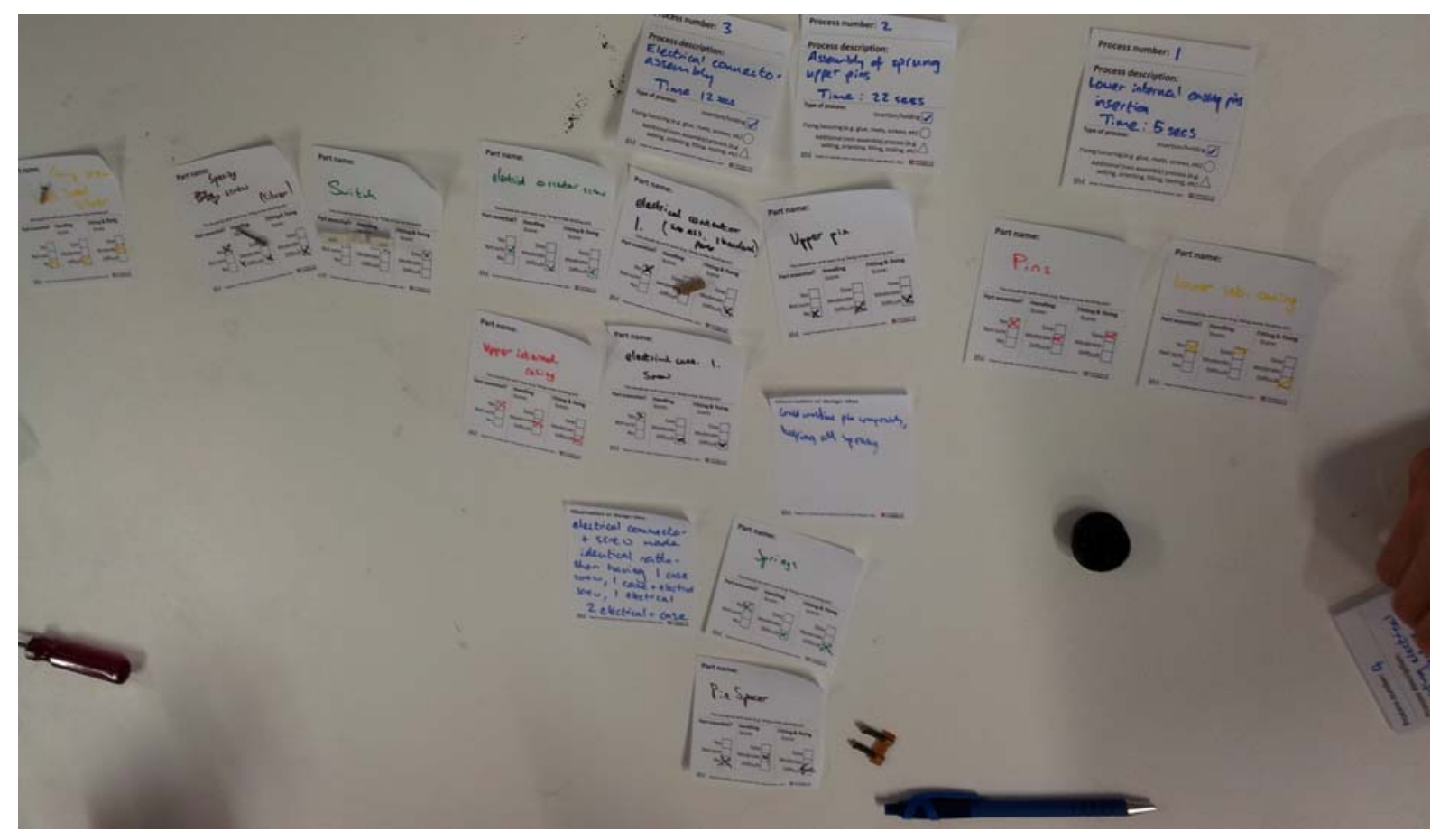

Fig 12: Photograph showing the DfA process 


\begin{tabular}{|c|c|c|c|c|c|}
\hline & 1 & 2 & 3 & 4 & 5 \\
\hline Product & A & A & A & $\mathrm{B}$ & B \\
\hline $\begin{array}{c}\text { Total } \\
\text { assembly } \\
\text { time } \\
\end{array}$ & 22 mins & 34 mins & 30 mins & 10 mins & 9 mins \\
\hline $\begin{array}{l}\text { Potential } \\
\text { assembly } \\
\text { time }\end{array}$ & 11 mins & 14 mins & 12 mins & 6 mins & 6 mins \\
\hline $\begin{array}{l}\text { Number of } \\
\text { parts }\end{array}$ & 28 & 24 & 30 & 67 & 62 \\
\hline $\begin{array}{c}\text { Number of } \\
\text { essential parts }\end{array}$ & 17 & 20 & 24 & 35 & 39 \\
\hline $\begin{array}{l}\text { Key issues / } \\
\text { improvements } \\
\text { / observations }\end{array}$ & $\begin{array}{l}16 \text { wires to } \\
\text { solder, lots } \\
\text { of small } \\
\text { washers and } \\
\text { screws. }\end{array}$ & $\begin{array}{c}\text { Improvements } \\
\text { to the chassis } \\
\text { and } \\
\text { connectors } \\
\text { would save } \\
60 \% \text { of the } \\
\text { time. }\end{array}$ & $\begin{array}{c}\text { Use snap fits, } \\
\text { simpler sub } \\
\text { assemblies }\end{array}$ & $\begin{array}{c}7 \text { different } \\
\text { wires to } \\
\text { solder. } \\
\text { Difficult } \\
\text { access. Lots } \\
\text { of screws. }\end{array}$ & $\begin{array}{c}\text { Could } \\
\text { significantly } \\
\text { reduce the } \\
\text { number of } \\
\text { screws, } \\
\text { improve self } \\
\text { location of } \\
\text { features, lots } \\
\text { of re- } \\
\text { orientations. }\end{array}$ \\
\hline
\end{tabular}

Table 1: Results from initial 'desk' analysis of products 


\begin{tabular}{|c|c|c|}
\hline Group & 1 & 2 \\
\hline Product & $\mathrm{A}$ & B \\
\hline $\begin{array}{l}\text { Total assembly } \\
\text { time per unit }\end{array}$ & 13 mins & $8.3 \mathrm{mins}$ \\
\hline $\begin{array}{l}\text { Potential assembly } \\
\text { time per unit }\end{array}$ & 7.5 mins & 7 mins \\
\hline $\begin{array}{l}\text { Value added time } \\
\text { in assembly }\end{array}$ & 5.5 & 4 mins \\
\hline $\begin{array}{l}\text { No. of assembly } \\
\text { staff/stations }\end{array}$ & 17 & 27 \\
\hline $\begin{array}{l}\text { Takt time range } \\
\text { for each station }\end{array}$ & $15-50$ seconds & 10-70 seconds \\
\hline $\begin{array}{l}\text { Maximum annual } \\
\text { production } \\
\text { volume } \\
\end{array}$ & 140,000 units & 100,000 \\
\hline $\begin{array}{c}\text { Key issues / } \\
\text { improvements / } \\
\text { observations }\end{array}$ & $\begin{array}{l}\text { Large range of takt-times, and thus } \\
\text { lots of non-value added time. Lots } \\
\text { of reorientations - At every stage, } \\
\text { the product was lifted, rotated and } \\
\text { turned over. Testing as a batch } \\
\text { process ( } 40 \text { units). Need to } \\
\text { simplify wiring and soldering. } \\
\text { Lots of potential for fixtures to } \\
\text { make things easier. }\end{array}$ & $\begin{array}{l}5 \text { people evidently not value } \\
\text { adding. Material is not presented } \\
\text { well to each workstation, lots of } \\
\text { bending, stretching etc. Some parts } \\
\text { on the floor behind operators. Lots } \\
\text { of reorientation especially to locate } \\
\text { wires for soldering. Lots of hand- } \\
\text { alignment. Wide variation in takt } \\
\text { times per station, thus some } \\
\text { operators not used fully. }\end{array}$ \\
\hline $\begin{array}{l}\text { Immediate } \\
\text { improvements }\end{array}$ & $\begin{array}{l}\text { Simplify the PCB assembly, } \\
\text { wiring and soldering. Pre-kitting } \\
\text { operations. Better line balancing. }\end{array}$ & $\begin{array}{l}\text { Trolleys to aid material movement. } \\
\text { Better supply of parts to operators. } \\
\text { Improvements to jigs and fixtures. }\end{array}$ \\
\hline $\begin{array}{l}\text { Medium term } \\
\text { improvements }\end{array}$ & $\begin{array}{l}\text { Integrate two PCBs into } 1 . \\
\text { Eliminate soldering by using } \\
\text { connectors. Fixtures to prevent } \\
\text { reorientations. }\end{array}$ & $\begin{array}{l}\text { Standardise some components. } \\
\text { Remove some complex parts. } \\
\text { Better line balancing. }\end{array}$ \\
\hline $\begin{array}{l}\text { Long term design } \\
\text { changes }\end{array}$ & $\begin{array}{l}\text { Single PCB. Assembly from } \\
\text { above. }\end{array}$ & $\begin{array}{l}\text { Major redesign to facilitate better } \\
\text { assembly }\end{array}$ \\
\hline
\end{tabular}

Table 2: results from observation of assembly on shop floor 